\title{
REPRESENTAÇÃO DA SITUAÇÃO DE RUA NO JORNALISMO ELETRÔNICO EM TEXTOS VERBO-VISUAIS - A VIOLÊNCIA EM DISCURSO NO CORREIO BRAZILIENSE (2011-2013)
}

\author{
Viviane de Melo Resende* \\ Universidade de Brasília \\ Departamento de Linguística \\ Brasília, DF, Brasil \\ Maria Carmen Aires Gomes ${ }^{* *}$ \\ Universidade Federal de Viçosa \\ Departamento de Letras e Artes \\ Viçosa, MG, Brasil
}

\begin{abstract}
Resumo: Este artigo é recorte de projeto de pesquisa em que se investigam os textos publicados entre 2011 e 2013 nos jornais web Correio Braziliense, O Globo e Folha de S. Paulo sobre população em situação de rua. Neste recorte, analisam-se apenas os 95 textos publicados no Correio Braziliense cruzando as temáticas situação de rua e violência, e as 19 imagens que compõem estes textos. As análises apresentadas são favorecidas pelo uso de software para análise qualitativa e têm por base teórico-metodológica a análise de discurso crítica e a gramática do design visual. Tomados juntos, os resultados de análise sugerem naturalização da violência contra a população em situação de rua, em um efeito retórico de distanciamento, que não provoca empatia entre quem lê o jornal e as pessoas vítimas da violência representada.
\end{abstract}

Palavras-chave: Análise de discurso crítica. Situação de rua. Violência. Jornalismo web.

1 INTRODUÇÃO

"Sabemos que há relação entre a violência institucionalizada e a violência privada.
Não podemos fingir que não sabemos disso."

(Angela Davis)

No projeto de pesquisa "Representação midiática da violação de direitos e da violência contra pessoas em situação de rua no jornalismo on-line” (CNPq 304075/20140), investigamos colaborativamente, com a participação da professora Carolina Lopes Araújo (FUP/UnB), das pesquisadoras Daniele Mendonça e Ingrid Ramalho (PPGL/UnB)

\footnotetext{
* Docente do Programa de Pós-graduação em Linguística - Laboratório de Estudos Críticos do Discurso, e do Programa de Pós-graduação em Desenvolvimento, Sociedade e Cooperação Internacional - Núcleo de Estudos de Linguagem e Sociedade. E-mail: vivianemelo@unb.br.

** Docente do Programa de Pós-graduação em Letras da UFV e do Programa de Pós-graduação em Estudos Linguísticos da Universidade Federal de Minas Gerais. E-mail: mcgomes@ufv.br.
} 
e das bolsistas Mariana Moura, Dara Abreu e Lygia Vaz (LIP/UnB), dados de notícias sobre a situação de rua no jornalismo web. Tomamos por base os estudos discursivos críticos, e tiramos proveito dos ambientes de investigação constituídos na Rede LatinoAmericana de Análise de Discurso Crítica e Pobreza (REDLAD), no Núcleo de Estudos de Linguagem e Sociedade (NELiS/UnB), no Laboratório de Laboratório de Estudos Críticos do Discurso (LabEC/UnB), no Programa de Pós-Graduação em Linguística (PPGL/UnB) e no Programa de Pós-Graduação em Estudos Linguísticos ${ }^{1}$ (Poslin/UFMG).

O objetivo do projeto é mapear representações da situação de rua na produção discursiva dos portais de três jornais - Folha de S. Paulo, O Globo e Correio Braziliense. Foi realizado mapeamento abrangente, com coleta de todos os textos publicados no período considerado para a pesquisa - de 2011 a 2013 - que resultaram das buscas pelas palavras-chave: "morador(a)(es) de rua", "pessoa(s) em situação de rua" e "população (em situação) de rua". As buscas nos três portais levaram a 752 textos.

Este artigo focaliza apenas as 95 notícias do corpus do Correio Braziliense (CB) que tematizam violência, objetivando responder às questões: (1) Quando o $C B$ cruza os temas da situação de rua e da violência, quais são as vozes convocadas a falar? (2) Como a população em situação de rua é avaliada nesses casos? (3) Como a população em situação de rua é representada imageticamente nesses veículos jornalísticos eletrônicos quando se trata desse corte temático? Essas perguntas são abordadas na perspectiva panorâmica possibilitada pelo software de organização e análise de dados qualitativos que usamos na pesquisa.

Na seção 2, discutimos noções necessárias para o estudo focalizado - conceitos e categorias da análise de discurso crítica, da gramática do design visual e da sociologia do corpo. Na seção 3, apresentamos procedimentos de organização, classificação e codificação dos dados. Na seguinte, focalizamos textos verbais, considerando, quando pertinente para comparação, o corpus de 166 textos do $C B$, mas com as lentes voltadas principalmente para os 95 textos sobre violência. Na seção 5, a análise volta-se para a representação imagética da violência nos dados do jornal. Por fim, apresentamos algumas considerações sobre esta etapa da investigação.

\section{DISCURSO, IMAGEM E CORPO: LINHAS GERAIS DE UM REFERENCIAL TEÓRICO-PRÁTICO}

A análise de discurso crítica, na versão que vimos discutindo e formulando (VIEIRA; RESENDE, 2016; RESENDE, 2017) com base na vertente de Fairclough (2003, 2010) e na escola latino-americana de ADC (PARDO, 2011; BOLIVAR, 2010; PARDO ABRIL, 2008), é uma teoria de discurso de base realista, que compreende que

\footnotetext{
${ }^{1}$ Este artigo apresenta um recorte dos resultados do projeto de pesquisa "Representação visual de pessoas em situação de rua no jornalismo on-line - Correio Braziliense e O Globo, de 2011 a 2013", projeto de pós-doutorado de Viviane de Melo Resende, com supervisão de Maria Carmen Aires Gomes, realizado junto ao Poslin, e parte integrante do projeto mais amplo CNPq 304075/2014-0. No projeto realizado junto à UFMG, consideram-se apenas os corpora do Correio Braziliense (166 textos) e de O Globo (121 textos).
} 
embora o discurso seja constitutivo da realidade, esta não se esgota em nosso conhecimento sobre ela. Trata-se, então, de uma abordagem que recusa perspectivas relativistas sobre realidade e discurso.

O mesmo se aplica à gramática do design visual: assim como as estruturas linguísticas, as estruturas visuais apontam para interpretações específicas da experiência e da interação social (KRESS; VAN LEEUWEN, 1996). Nessa abordagem, entende-se que "[e]struturas visuais não reproduzem simplesmente as estruturas da realidade. Ao contrário, elas produzem imagens da realidade que estão vinculadas ao interesse das instituições sociais dentro das quais são produzidas, distribuídas e lidas" (p. 64). Não se trata tampouco, portanto, do elemento discursivo como reflexo da realidade, mas como construção resultante de ordenações discursivas próprias de cada sociedade, com ênfase também no aspecto constitutivo do discurso (VAN LEEUWEN, 2005).

Três noções decorrentes do aspecto duplo-constitutivo do discurso são teoricamente relevantes para discutir relações de discurso-e-sociedade. Em primeiro lugar, discursos materializados em textos têm efeitos: realizam mudanças no mundo. Em segundo lugar, diferentes discursos são diferentes modos de representar realidades, e trata-se sempre de diferenças posicionadas - situadas e decorrentes de posições em jogos de interesses e relações de poder. Em terceiro lugar, discursos identificam e participam, portanto, na construção discursiva de identidades. Esses três aspectos são base da teoria de discurso formulada por Fairclough (2003).

Discursos como modos de representação são concebidos como formas de conhecimento socialmente construído sobre algum aspecto da realidade, e que impactam a própria realidade social e as identidades-alteridades constituídas nesse entremeio, o que é sempre desenvolvido em contextos específicos. Entrecruzam-se, portanto, os eixos do poder, do saber e da ética (FOUCAULT, 1984): o poder de definir como se compreende um aspecto da realidade e como se deve identificar em relação a ele.

Por isso, à semiótica social interessam os modos como pessoas usam recursos semióticos em contextos específicos, em práticas e instituições, e como esses recursos são regulados. Quando se toma um corpus de dados textuais oriundos de um domínio discursivo e temático, por exemplo, do jornalismo eletrônico sobre a situação de rua, observam-se continuidades muito marcantes que apontam para as ordens de discurso postas em relação. A ordenação social do potencial semiótico torna-se então um elemento de investigação.

A análise de notícias para a abordagem de problemas sociais como as representações da violência justifica-se porque se entende a notícia reorganizando séries de eventos relatados fora de sua ordem lógica e cronológica, e por isso é uma forma de regulação social. Assim, para Fairclough (2003), a produção de histórias em notícias é reconstrução de acontecimentos fragmentários como eventos distintos e separados, incluindo certos acontecimentos e excluindo outros, assim como organizando esses eventos construídos em relações particulares. A produção de notícias, portanto, é um processo interpretativo e construtivo, e não simplesmente um relato.

Para Seara (2016, em palestra), “[t]oda violência física é sempre precedida de violência verbal; há toda uma gramática da violência que leva à opressão e à perda de direitos". À população em situação de rua, avaliações como incômoda, perigosa e 
oportunista são mais recorrentes em notícias. É classificada de perigosa mesmo sendo vítima de violência; é classificada de incômoda, mesmo sendo ela a sofrer o impensável incômodo da vida nas ruas; é classificada de oportunista, mesmo estando na mais periférica margem do sistema de vantagens desigualmente distribuídas no modo de produção capitalista. Essas classificações, produzidas ordinariamente, e circuladas nos mais variados contextos, reificam a violência.

Poderíamos nos perguntar que atores sociais são representados imageticamente, em fotografias publicadas em jornais, como corpos mortos que se mostram pelo chão, cobertos com trapos e sem velórios. Somos todos humanos, mas a humanidade de alguns é diluída ou mesmo negada em textos e imagens que expõem corpos com os quais não nos identificamos (FANON, 2015). Aí se realiza a gramática de violência de que nos fala Seara (2016). Butler também ressalta a fragilidade de determinados corpos em certas regulações de instituições de poder, chamando a pensar que os conceitos de precariedade e vulnerabilidade estão diferentemente distribuídos, pois certas vidas são merecedoras de amparo, de existência, e outros corpos/vidas são vistos como dispensáveis. As pessoas em situação de rua não se encaixariam em corpos atuantes, mas em um 'não-lugar' que, embora muito visível, adquire visibilidade negativa. Os jornais reiteram práticas de desumanização dessas pessoas, estimulando potencialmente semioses de precariedade, não demandando outro tipo de resposta moral.

Le Breton (2017) enfatiza que o estatuto do corpo é variável através da história: "Num mundo difícil de discernir, o corpo se torna espaço de uma soberania fugidia", e se mercantiliza, torna-se suporte para encarnar identidades de decoração na coautoria de si mesmo. Mas aqui podemos nos perguntar como articular o debate sobre a mercantilização do corpo no caso de pessoas que não possuem meios de adquirir essa corporeidade simbólica no mercado. Se nas sociedades capitalistas a identidade se dissolve no exterior de si, em função das informações que se mostram aos outros, então a impossibilidade de acessar estilos mercantilizados de seu corpo coloca as pessoas em situação de rua em situação de 'não ser'? Ademais, pessoas em situação de rua têm pouco ou nenhum domínio sobre as formas como são representadas em notícias.

Nos dados do $C B$, veremos a cobertura noticiosa de casos de assassinato de pessoas em situação de rua, inclusive pelo fogo. $\mathrm{O}$ assassinato pelo fogo pode ser pensado como aniquilação total do corpo, totalmente destruído, apagado da existência. Ao tratar deste tema, não podemos esquecer os 20 anos do assassinato de Galdino, indígena Pataxó que, em 1997, tendo vindo a Brasília para as comemorações da assim chamada 'semana do índio', e não tendo onde pernoitar na cidade, decidiu dormir em um ponto de ônibus, na Asa Sul, próximo ao centro da cidade. Enquanto Galdino dormia, um grupo de jovens que depois veio a público tratar-se de filhos da elite local - considerou uma boa diversão jogar combustível sobre seu corpo e atear fogo. Antes de morrer, Galdino teria perguntado "Por que fizeram isso comigo?". A resposta veio nos tribunais, quando os advogados de seus assassinos justificaram o crime: os jovens não sabiam que se tratava de um indígena, pensaram que fosse "um mendigo", que assassinaram por "brincadeira". Estar em situação de rua passou a ser ali uma justificativa para aniquilação completa da existência por meio do fogo. Essa justificativa não envolve apenas a destruição física de que padeceu Galdino, mas traz em si a destruição simbólica de todo um grupo social, que não se 
percebe como merecedor da existência, que não tem "resistência ontológica", nos termos de Fanon (2015). Como afirma Tiburi (2013, p. 23), essa exclusão "é produzida no discurso: seu lugar é o silêncio que, em termos sociais muito concretos, realiza-se na injustiça de não poder existir".

\section{A COMPOSIÇÃO DO CORPUS E O TRATAMENTO DOS DADOS}

Nesta seção, dedicamo-nos a detalhar procedimentos adotados no projeto integrado, desde a coleta de dados até sua análise. O projeto tem como objetivo central analisar representações que circulam no domínio discursivo do jornalismo on-line a respeito de pessoas em situação de rua. Foram considerados três jornais de circulação nacional no Brasil: O Globo (oglobo.globo.com/), Correio Braziliense (correioweb.com.br) e Folha de S. Paulo (folha.uol.com.br), e foram coletadas todas as notícias publicadas entre 2011 e 2013 e acessíveis por meio de argumentos de busca ligados à situação de rua. ${ }^{2}$

Os dados foram organizados com auxílio do NVivo 11 Pro. Primeiro, criamos pastas para a simples separação dos dados em função dos anos de publicação e das temáticas desenvolvidas nos textos. A leitura inicial dos dados sugeriu a separação dos dados em cinco temas: drogas, políticas públicas, violação de direitos, violência e outros temas. Os 166 textos publicados pelo $C B$ no intervalo considerado organizam-se assim em termos temáticos: drogas: três; outros temas: 18; políticas públicas: 32; violação de direitos: 18; violência: 95 . A frequência muito maior de textos tematizando violência levou-nos à escolha desse foco para esta reflexão.

O uso de pastas foi uma forma eficiente de iniciar a organização dos dados, mas para conseguirmos fazer cruzamentos entre essas informações (anos e temas) com os demais itens de codificação (ver a seguir), foi necessário transferi-las também para classificações (RESENDE, 2016). Os dados também foram organizados em categorias de preparação, com o objetivo de separar os dados em termos de mais dois conjuntos de informações: a assinatura (trata-se de texto assinado ou não?) e a editoria de publicação (em quais cadernos dos jornais publicam-se notícias e reportagens sobre a população em situação de rua?). Os textos publicados na plataforma on-line do jornal Correio Braziliense entre os anos de 2011 e 2013 são predominantemente narrativos (118 de 166), massivamente localizados no caderno Cidades (147 de 166) e frequentemente não incluem a assinatura de quem escreveu a matéria (114 de 166). Isso já nos leva a alguns indícios sobre a abordagem da situação de rua no jornal: trata-se antes de narrar fatos (em notícias) do que de refletir sobre eles (em reportagens) ou traçar relações causais; há mais notícias locais de âmbito policial, pois é no caderno Cidades que esse tipo de notícia se concentra nesse jornal, e há predominância de textos não assinados, o que já sugere não se tratar de reportagens, artigos, crônicas, colunas, mas de notícias ou curtos informes que reproduzem boletins das forças de ordem pública.

\footnotetext{
2 Os argumentos de busca utilizados nos portais on-line desses jornais foram "morador(a)(es) de rua", "pessoa(s) em situação de rua", "população (em situação) de rua". Dessas buscas, resultaram 752 textos: 166 do Correio Braziliense; 121 de O Globo, e 465 da Folha de S. Paulo. Diante desses corpora, julgamos necessário o uso de software para a organização dos dados.
} 
No caso das imagens, interessou-nos investigar os corpos representados, então as classificações acrescentadas foram referentes a pertencimentos de classe, raça e gênero. Dos 166 textos publicados sobre situação de rua no $C B$ entre 2011 e 2013, apenas 35 contêm fotografias em sua composição e, desses, 19 são sobre violência, a temática mais presente nas notícias e também a mais representada imageticamente no jornal.

Em seguida, realizamos a principal etapa do trabalho de codificação: o mapeamento das categorias de análise. Nesta etapa pré-analítica de exploração do NVivo, consideramos as seguintes categorias de análise para os aspectos verbais: 'intertextualidade e fontes jornalísticas'; 'modos de avaliação de pessoas em situação de rua'; 'modos de referência a pessoas em situação de rua' e 'modos de representação de pessoas em situação de rua'. À exceção da categoria 'modos de representação de pessoas em situação de rua', em que a codificação foi teoricamente dirigida pela teoria de representação de atores sociais proposta por van Leeuwen (1997, 2008), as demais categorias foram preenchidas indutivamente, isto é, os códigos foram registrados conforme o mapeamento sugerido pela leitura dos próprios dados. Assim, temos um conjunto de vozes mapeadas em 'intertextualidade' que não é necessariamente o mesmo para cada veículo, e assim também para os 'modos de avaliação' e os 'modos de referência'.

As categorias analíticas para mapeamento das fotografias ${ }^{3}$ foram teoricamente motivadas pela gramática do design visual proposta por Kress e van Leeuwen (1996), cujas categorias foram apropriadas de acordo com as necessidades analíticas apresentadas nos dados. A codificação nessa etapa considerou, para o significado composicional, a 'saliência', que diz respeito ao elemento mais proeminente na imagem e cujas categorias foram levantadas indutivamente dos dados; para o significado interativo, os sistemas de olhar (categorias: demanda e oferta) e enquadramento (categorias: plano geral, plano médio e primeiro plano); e, para o significado representacional, as categorias de 'cenário' e 'corpo representado' foram preenchidas indutivamente dos dados, e os 'tipos de estruturas de representação’ tiveram mapeamento teoricamente motivado.

Na próxima seção, vamos explorar os dados verbais cruzando uma informação classificatória - o tema 'violência' - e dois sistemas de codificação - 'intertextualidade e fontes jornalísticas' e 'modos de avaliação de pessoas em situação de rua'.

\section{AVALIAÇÃO DE PESSOAS EM SITUAÇÃO DE RUA NO CORREIO BRAZILIENSE: UMA FORMA DE VIOLÊNCIA}

As perguntas que orientam nossas descobertas nesta seção, favorecidas por recursos do software, são duas, a saber: (1) Quando o $C B$ cruza os temas da situação de rua e da violência, quais são as vozes convocadas a falar? (2) Como a população em situação de rua é avaliada nesses casos?

\footnotetext{
${ }^{3}$ Os textos não usaram desenhos, ilustrações ou qualquer tipo de infográfico (tabelas, quadros) para representar a violência ou os atos de violência, mas fotografias, predominantemente naturalísticas e realísticas, com saturação, modulação e diferenciação de cores, ou seja, não são monocromáticas ou estão em preto e branco, e há uma construção de gradação de alta modalização do "real".
} 
A definição dessas perguntas foi orientada por pesquisas anteriores, em que percebemos que, em jornais, a população em situação de rua é frequentemente avaliada, por outros grupos sociais, como perigosa, incômoda e oportunista (RESENDE, 2015b, por exemplo). Percebemos isso em estudos bastante localizados, voltados à análise de poucos textos, ou mesmo de apenas um texto por vez, tomado como objeto suficiente para o estudo de um caso específico (RESENDE; SILVA, 2017; RESENDE, 2015a; 2015b; 2012; RESENDE; RAMALHO, 2013; RESENDE; SANTOS, 2012). Agora que contamos com três corpora que dão conta de todos os textos que referem diretamente a população em situação de rua em três jornais pelo período de três anos, podemos nos perguntar, de forma mais abrangente, sobre as vozes convocadas quando se trata de pautar o assunto. Aqui, nosso foco serão apenas os 95 textos do $C B$ classificados na temática da violência, mas quando pertinente para fins de comparação, faremos referência ao corpus total do $C B$, que já foi apresentado em Resende (2016).

Para chegar aos resultados analíticos que passamos a apresentar, utilizamos a ferramenta de análise 'matriz de codificação', que nos permite cruzar informações codificadas em diferentes nós/ classificações. Assim, tomamos os dados do $C B$ classificados na temática da violência e observamos como se preenchem os subnós de 'intertextualidade e fontes jornalísticas', o que nos permite ver quais grupos sociais são convocados a falar sobre situação de rua e violência no jornal entre 2011 e 2013. A Tabela 1, a seguir, mostra resultados de matriz que permitem comparar a presença de vozes nos textos sobre violência com o resultado para os dados totais do projeto. Obviamente, cada texto pode incluir um conjunto de variadas vozes.

Tabela 1 - Intertextualidade e fontes jornalísticas CB/ CB-Violência

\begin{tabular}{l|r|r}
\hline Vozes convocadas a falar & Correio Braziliense & CB Violência \\
\hline Ativistas e religiosos & 4 & 3 \\
Coletivos de pessoas em situação de rua & 6 & 0 \\
Empresários & 1 & 0 \\
Entidades escolares & 3 & 0 \\
Familiares de pessoas em situação de rua & 3 & 2 \\
Moradores e trabalhadores locais & 50 & 17 \\
Outras pessoas & 10 & 5 \\
Pessoas em situação de rua & 67 & 20 \\
Polícia & 67 & 58 \\
Testemunhas & 23 & 18 \\
Vozes da lei & 91 & 61 \\
Vozes de especialistas & 69 & 10 \\
Vozes do governo & 60 & 3 \\
Vozes médicas & 12 & 9 \\
\hline Total & 166 & 95 \\
\hline
\end{tabular}

Fonte: Elaboração própria

Comparando as duas colunas com dados de números de referências codificadas para essas vozes, dois aspectos chamam a atenção: vozes da lei, vozes de especialistas e vozes de pessoas em situação de rua, embora tenham presença expressiva no corpus total, aparecem pouco quando se trata de tematizar violência, especialmente se considerarmos que nesse tema se classifica mais da metade dos textos desse corpus (95 de 166). Quanto 
às vozes do governo e de especialistas, o mapeamento dessas vozes nos dados mostra que sua presença é mais recorrente nos textos classificados na temática de políticas públicas e violação de direitos, para o caso do governo, e de políticas públicas e outros temas para o caso de especialistas. À população em situação de rua, por sua vez, o espaço de fala reservado é mais expressivo em textos classificados como outros temas.

\begin{abstract}
Trata-se de textos que narram histórias singulares, como a aprovação de uma pessoa em situação de rua no vestibular, o caso de uma pessoa desaparecida que foi encontrada por um homem em situação de rua, um "andarilho-jardineiro" que cuida de jardins públicos por iniciativa própria etc. Como são poucos os textos classificados nessa temática (cinco de 2011, cinco de 2012 e nove de 2013: 19 textos), é notável que estejam aí as mais frequentes falas de pessoas em situação de rua. (RESENDE, 2016, p. 26).
\end{abstract}

O tema da violência é o mais carregado de diferentes vozes, o que pode indicar um tratamento mais complexo desse tema no jornal, ou pode ser simples decorrência do fato de que a violência é o tema mais frequente nos dados do $C B$, demandando maior articulação intertextual. É de se notar, também, que com tantas vozes convocadas a tratar de violência os coletivos de pessoas em situação de rua (seus movimentos sociais) não tenham espaço de fala sobre o assunto (nem sobre violação de direitos), especialmente num quadro de violência como o observado em Brasília. Muitas vozes falam sobre violência, mas a presença é muito mais expressiva, em relação às demais, quando se trata das vozes da lei e da polícia. Por um lado, pode-se dizer que essa presença é esperada, já que trata, na maior parte dos casos, de notícias de teor policial. Por outro lado, isso mostra também que a violência contra a população em situação de rua é tratada muito mais no âmbito do caso policial que da vida mesmo das pessoas - por exemplo, familiares de pessoas em situação de rua só são convocados/as sobre esse assunto duas vezes nos textos do corpus. Os relatos não tratam da vida das pessoas, mas do viés muito específico da segurança e da ordem públicas.

Salvando os resultados da consulta anterior especificamente no que se refere às vozes que se articulam para falar de violência, e cruzando esse resultado (violência/ intertextualidade) com os modos de avaliação de pessoas em situação de rua, podemos mapear as avaliações que o jornal atribui a outras vozes nos textos:

Tabela 2 - Violência/Intertextualidade X Modos de avaliação

\begin{tabular}{l|r}
\hline Avaliação CB & Violência X Intertextualidade \\
\hline Discriminadas & 3 \\
Incômodas & 7 \\
Pacíficas & 1 \\
Perigosas & 10 \\
Queridas & 2 \\
Trabalhadoras & 2 \\
Tranquilas & 3 \\
Viciadas & 9 \\
Violentas & 1 \\
\hline
\end{tabular}

Fonte: Elaboração própria 
No conjunto de textos que tematizam a violência, vimos que 11 diferentes vozes são convocadas a falar. Nem sempre nessas vozes articulam-se avaliações, mas, algumas vezes, sim. Nesses casos, os modos de avaliação mais presentes são 'perigosas', 'viciadas' e 'incômodas', mas também aparecem avaliações positivas, como 'pacíficas', 'queridas', 'trabalhadoras' e 'tranquilas'. No caso dessas últimas, é importante acrescentar que aparecem em apenas dois textos: uma no texto "Corpo de morador de rua que morreu queimado é enterrado nesta tarde", e as demais no texto "Moradores de rua do Guará temem retorno de agressores", cuja manchete é assim ampliada: "Na última quinta-feira um morador de rua teve o corpo queimado por agressores e morreu neste sábado".

Tomando-se todas as avaliações positivas de pessoas em situação de rua nos 166 textos do corpus do $C B$, articuladas ao mapeamento de intertextualidade ou não, observamos que as avaliações positivas concentram-se em duas classificações temáticas: violência e outros temas, e em apenas seis textos: esses dois de violência e os textos "Exmorador de rua se forma em Pedagogia na UnB", "Ex-morador de rua supera as dificuldades e comanda restaurante na Asa Norte", "Morador de rua encontra Felipe após duas semanas", "Morador de rua que encontrou universitário também estava desaparecido", "Familiares de estudante desaparecido adotam morador de rua como herói" e "Morador de rua que encontrou Felipe Dourado fala com a mãe após cinco meses". Os quatro últimos textos referem-se todos à mesma história: de um jovem estudante universitário com problemas psiquiátricos, desaparecido e que foi encontrado graças a Adeilson Mota, então em situação de rua. Assim, nos 166 textos do $C B$ analisados, apenas quatro pessoas em situação de rua recebem avaliação positiva, e uma delas é assim avaliada após ter sido brutalmente assassinada. No conjunto dos 166 textos, as avaliações mais recorrentes são, nesta ordem, perigosas, incômodas, viciadas e oportunistas, que juntas somam mais de $80 \%$ das avaliações mapeadas no corpus.

\section{Figura 1 - Nuvem de Palavra, com destaques}

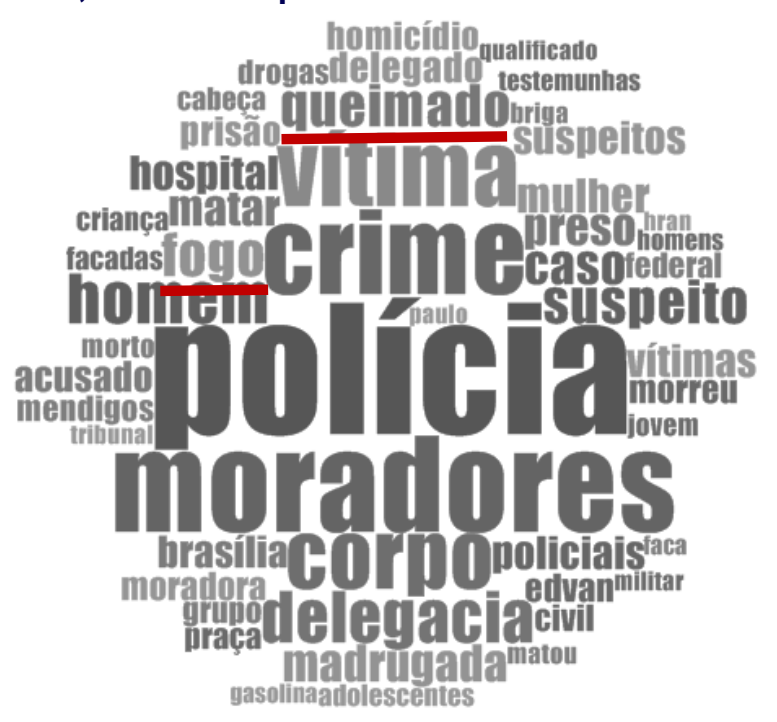

Fonte: Elaboração própria a partir do NVivo 11 Pro, com destaques acrescentados 
Outro recurso que o software possibilita é a pesquisa de frequência de palavras. Nesse tipo de exploração analítica no NVivo, é possível conhecer as palavras mais usadas em um corpo de dados textuais. No caso dos textos tematizando violência no corpus do $C B$, esse recurso retornou uma nuvem (ver figura 1, destaques acrescentados), composta das 50 palavras de no mínimo quatro letras mais frequentes nos 95 textos em foco:

Figura 2 - Árvore de Palavra - fogo

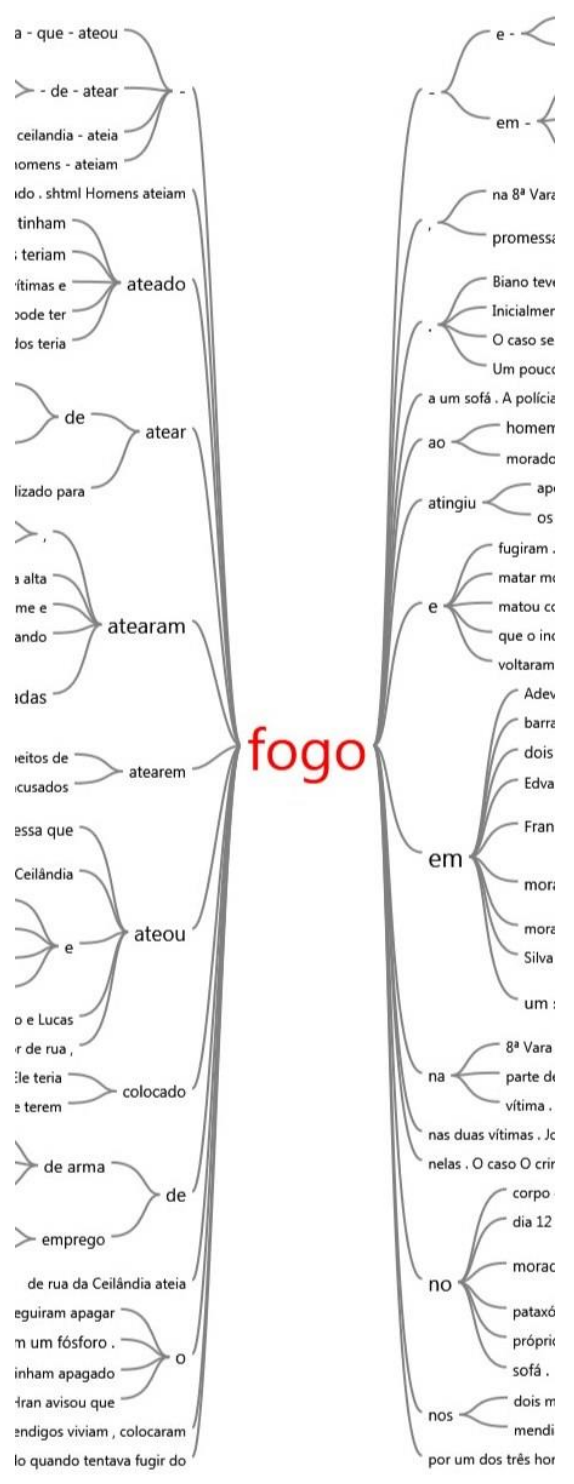

Fonte: Elaboração própria a partir do NVivo 11 Pro

Na nuvem gerada, o tamanho de cada palavra indica sua frequência, de modo que as palavras mais frequentes são polícia, moradores, crime, vítima, corpo, e assim sucessivamente, como indicado na imagem. A alta frequência dessas palavras não surpreende, pela delimitação temática do conjunto de textos analisados. Mas, como os destaques na nuvem das 50 palavras mais frequentes indicam, chamou-nos atenção a 
frequência das palavras 'fogo' e 'queimado', respectivamente nona e décima palavras mais frequentes nos 95 textos do $C B$ tematizados em violência. Isso nos levou a processar outra consulta, que, pelo recurso de pesquisa de texto, nos mostrou a árvore de palavra para 'fogo' nesse corpo de textos (ver figura 2). $\mathrm{Na}$ árvore de palavras, explicita-se o padrão de colocação da palavra fogo com atear (ateou, ateia, ateiam, ateado, atearem, atearam) e colocar, de mesmo sentido nessa colocação. Há apenas uma exceção, em referência a 'arma de fogo'.

A árvore de palavra para 'queimado' também foi gerada. O principal padrão de colocação de 'queimado' nesses textos é com 'corpo', mas também são recorrentes colocações com 'morador de rua'.

Figura 3 - Árvore de Palavra - queimado

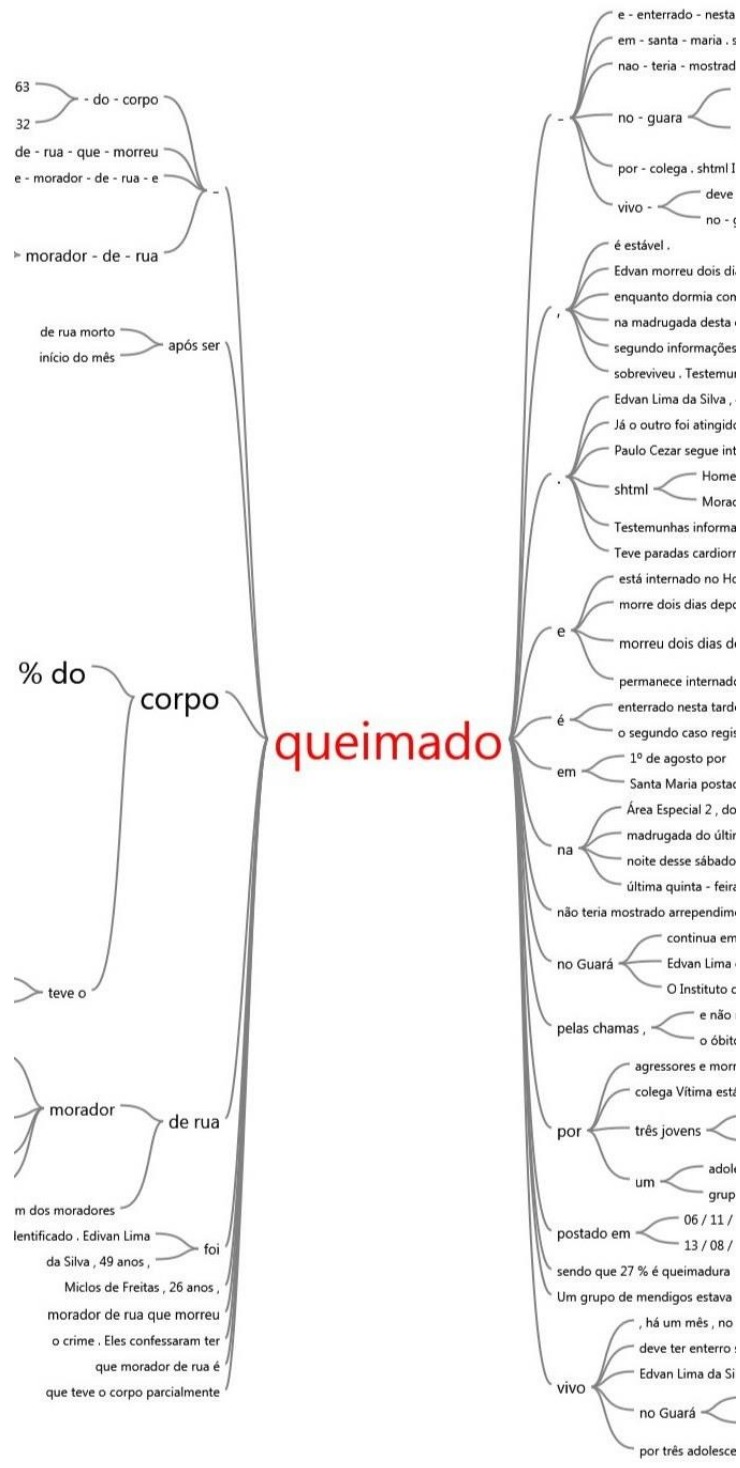

Fonte: Elaboração própria a partir do NVivo 11 Pro

RESENDE, Viviane de Melo; GOMES, Maria Carmen Aires. Representação da situação de rua no jornalismo eletrônico em textos verbo-visuais - a violência em discurso no Correio Braziliense (2011-2013). Linguagem em (Dis)curso - LemD, Tubarão, SC, v. 18, n. 1, p. 165-191, jan./abr. 2018. 
Os textos que articulam nesse corpus a situação de rua e a violência são quase sempre notícias de fatos violentos dos quais pessoas em situação de rua são vítimas. $\mathrm{O}$ modo de referência mais frequente é, como já se espera, morador/a de rua. Mas o segundo modo mais frequente como os textos desse corpus referem pessoas em situação de rua é vítima (102 referências em 56 textos). São histórias de pessoas que tiveram o corpo queimado, de pessoas que foram envenenadas, que foram alvejadas enquanto dormiam. Parece paradoxal que o mesmo grupo populacional a que se dirige forma tão terrível de violência como o assassinato pelo fogo seja tão frequentemente avaliado como perigoso, e não seja avaliado como vulnerável (RESENDE, 2016).

Na próxima seção, nosso foco restringe-se aos 19 textos articulando situação de rua e violência no corpus do $C B$ que contêm fotografias em sua composição.

\section{IMAGENS DA VIOLÊNCIA NO CORREIO BRAZILIENSE}

Agora, buscamos responder à terceira questão que orienta este artigo: (3) O que as imagens presentes nos textos, quando é o caso, nos dizem a respeito do cruzamento dos temas da situação de rua e da violência no $C B$ ?

Tomamos como categorias analíticas para mapeamento das 19 fotografias categorias da gramática do design visual (GDV; KRESS; VAN LEEUWEN, 1996), considerando a 'saliência', no significado composicional; os sistemas de olhar e enquadramento, no significado interativo; e o sistema de 'estruturas de representação', no significado representacional. Para este último significado, agregamos ao quadro analítico da GDV as categorias de 'cenário', referente à contextualização, um dos critérios para se analisar a modalidade visual, e 'corpo representado', um acréscimo indicado por necessidades analíticas de nosso corpus e dos objetivos da pesquisa.

Para cada um dos três significados (composicional, interativo e representacional), a discussão analítica aqui será organizada pelos padrões mais recorrentes para cada categoria. Iniciemos pelo significado composicional, cujos resultados analíticos estão resumidos a seguir na Tabela 3 .

Tabela 3 - Resumo do mapeamento de categorias para imagens: significado composicional

\begin{tabular}{l|c}
\hline \multicolumn{2}{c}{$\begin{array}{c}\text { IMAGENS - TEXTOS CORREIO BRAZILIENSE: VIOLÊNCIA } \\
\text { SIGNIFICADO COMPOSICIONAL }\end{array}$} \\
\hline \multicolumn{2}{c}{ Saliência } \\
\hline Agressor/a de pessoa em situação de rua & 2 \\
Escrita & 1 \\
Força de segurança & 4 \\
Não humano & 9 \\
Pessoa em situação de rua & 3 \\
\hline
\end{tabular}

Fonte: Elaboração própria 
O significado composicional refere-se a como recursos semióticos operam na composição da imagem como texto, e nesse sentido a saliência diz respeito a recursos utilizados na imagem que acarretam a colocação dos participantes representados em maior ou em menor evidência, atribuindo proeminência e projetando valor sobre o que é representado na imagem, pelo uso de cores, tamanho e contraste. Como a Tabela 3 indica, o padrão mais recorrente nas 19 imagens é salientar elementos não humanos. As nove imagens que se compõem assim referem-se a cinco eventos:

1. Santa Maria, 6/3/2012: grupo de pessoas em situação de rua foi atacado com fogo, e uma pessoa morreu - o $C B$ publica uma notícia, no mesmo dia.

2. Taguatinga, 10/3/2012: duas pessoas em situação de rua foram assassinadas a tiros - o $C B$ publica uma notícia, no mesmo dia.

3. Guará, 1/8/2013: grupo de pessoas em situação de rua foi atacado com fogo, e uma pessoa morreu - o $C B$ publica quatro notícias entre $1^{\circ}$ de agosto e 6 de setembro.

4. Guará, 10/8/2013: pessoa em situação de rua foi atacada com fogo, tem $32 \%$ do corpo queimado e sobrevive - o $C B$ publica uma notícia, no mesmo dia.

5. Brazlândia, 21/8/2013: pessoa em situação de rua foi espancada até a morte - o $C B$ publica uma notícia, no mesmo dia.

Veremos cada caso considerando as fotografias e as manchetes correspondentes. As oito imagens com codificação de saliência em "não humano" conduzirão esta análise, mas aproveitaremos a reprodução de cada imagem para comentar também sua codificação em outras categorias.

O primeiro caso foi noticiado no texto "Polícia prende suspeitos de incendiarem moradores de rua em Santa Maria", e a fotografia que compõe a notícia tem em saliência um elemento metafórico: uma árvore queimada no ataque que representa o evento noticiado.

\section{Figura 4 - Fotografia 6/3/2012 com faixa de codificação}

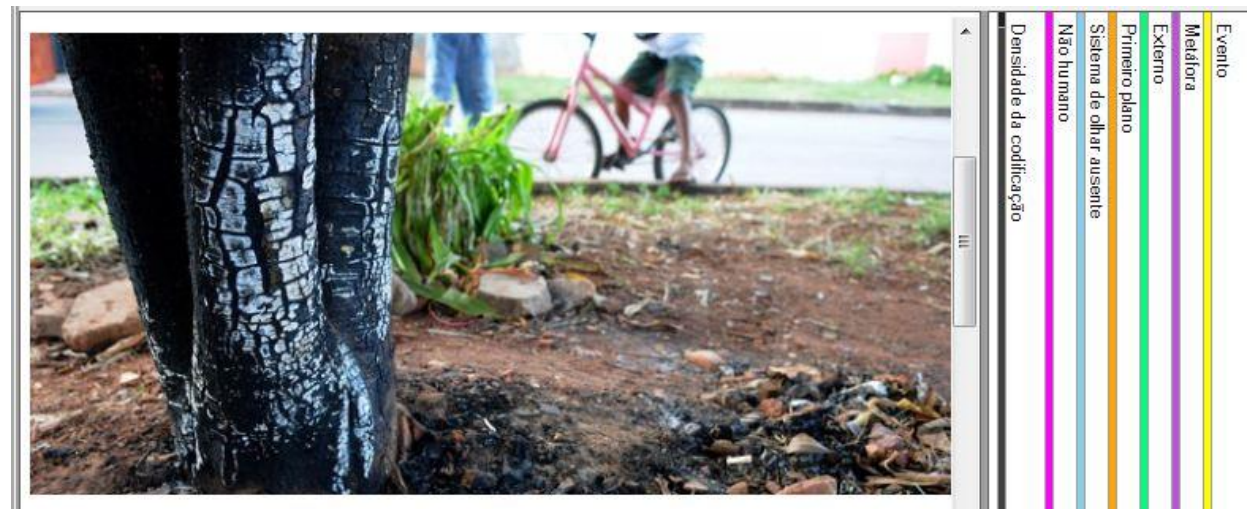

Fonte: Elaboração própria a partir do NVivo 11 Pro e de imagem disponível na Internet ${ }^{4}$

\footnotetext{
${ }^{4}$ http://www.correiobraziliense.com.br/app/noticia/cidades/2012/03/06/interna_cidadesdf,292122/policiaprende-suspeitos-de-incendiarem-moradores-de-rua-em-santa-maria.shtml.
} 
O elemento saliente aparece destacado pela intensidade do foco, com alta proximidade em primeiro plano e elevado detalhamento de cores e textura. $\mathrm{O}$ ataque com fogo é representado por uma árvore, que se torna uma representação metafórica do corpo de José Edson de Freitas, que tinha 26 anos, "teve cerca de $63 \%$ do corpo queimado pelas chamas" e "faleceu, horas depois do crime", bem como das pessoas que estavam com ele e sobreviveram ao ataque. Essa representação impersonalizada do grupo afina-se com o conteúdo verbal da manchete, em que se lê "Polícia prende suspeitos de incendiarem moradores de rua em Santa Maria" - essa colocação do verbo 'incendiar' com um complemento humano ("moradores de rua") não é um padrão, e portanto a manchete também objetifica o grupo representado. Uma busca no próprio portal do $C B$ por "suspeito(s) de incendiar" retorna resultados como "suspeitos de incendiar ônibus" e "suspeito de incendiar casa": a colocação com meta [+humana] encontrada apenas com o complemento "moradores de rua". Essa ruptura no padrão e a ocorrência apenas de "moradores de rua" como complemento humano de 'incendiar' nos diz a respeito da representação desse grupo populacional no $C B$ e do quadro interpretativo que o jornal sugere.

Trata-se de uma representação imagética conceitual por meio de um processo simbólico sugestivo, pois além de a árvore portar o atributo "queimado", o seu entorno sugere que algo ali aconteceu. Realiza também uma estrutura representacional de evento, ou seja, há uma ação representada (a de atear fogo), mas essa ação se representa apenas pela meta: José Edson de Freitas, cujo corpo é representado metaforicamente pela árvore queimada, em cenário externo. Segundo Biasi-Rodrigues e Nobre (2010), podemos assumir que há um processo simbólico subjacente à estrutura representacional de evento.

O segundo texto com saliência não humana tem manchete "Dois moradores de rua foram executados na manhã deste sábado em Taguatinga". A seguir, a fotografia que compõe o texto com as faixas de codificação obtidas no NVivo:

\section{Figura 5 - Fotografia 10/3/2012 com faixa de codificação}

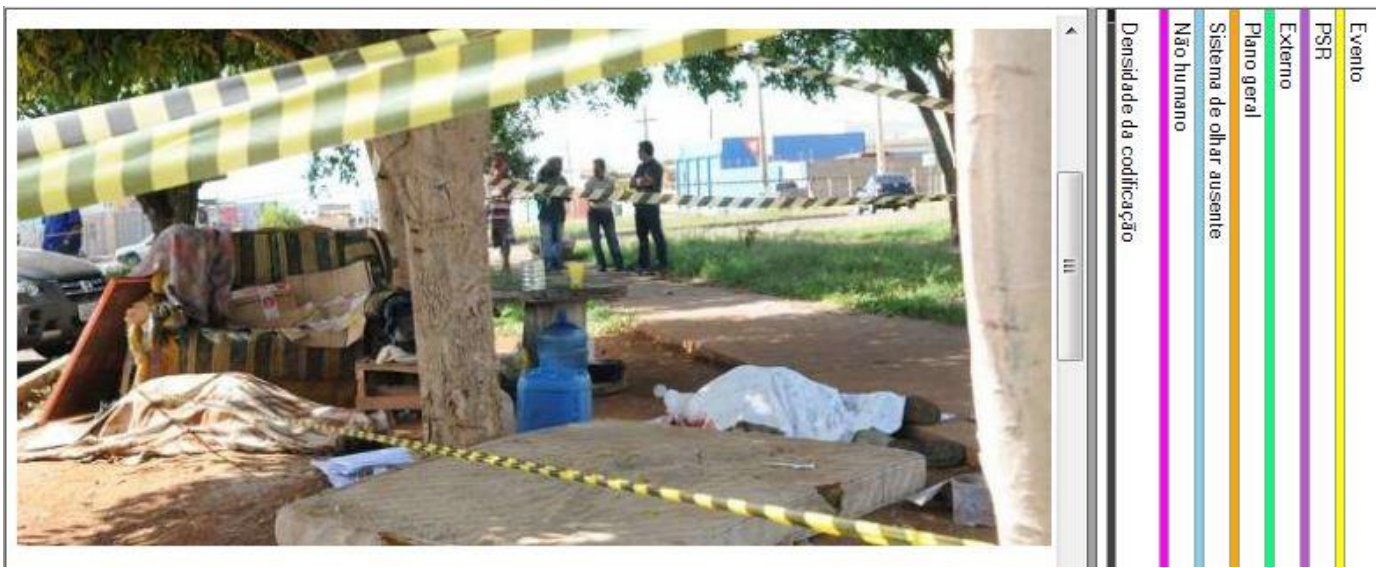

Fonte: Elaboração própria a partir do NVivo 11 Pro e de imagem disponível na Internet ${ }^{5}$

\footnotetext{
${ }^{5}$ http://www.correiobraziliense.com.br/app/noticia/cidades/2012/03/10/interna_cidadesdf,292790/doismoradores-de-rua-foram-executados-na-manha-deste-sabado-em-taguatinga.shtml
} 
A fotografia atribui saliência a elementos não humanos, que estão postos à esquerda, influenciando uma trajetória de leitura que vai da presença policial representada na faixa que isola o cenário - em primeiro plano e delimitando uma linha de frame - ao espaço ocupado e sua desordem e, por fim, ao corpo morto e coberto com um lençol branco. A intensidade do foco é maior sobre as árvores e o sofá - retratado em ângulo horizontal oblíquo, sugerindo distanciamento de realidade entre o/a leitor/a da imagem e o mundo desordenado, o que assim reforça os modos de avaliação recorrentes, que vimos anteriormente. A fotografia mostra um detalhamento desse evento por meio da meta (corpo envolto pelo lençol) que sugere que ocorreu um crime; não aparece nenhuma referência a quem cometeu o assassinato, mas há um esforço em descrever o espaço em que a vítima residia. Assim como na imagem anterior, há também uma representação conceitual simbólica que traz em si um atributo específico de não corpo, não lugar, não existência.

Em cenário externo, a imagem inclui as circunstâncias espaciais na representação, e as pessoas ao fundo fazem parte dessa contextualização, fora da linha de frame formada pela faixa da polícia. Trata-se de uma imagem a ser contemplada: um corpo angularmente distante do/a leitor/a, sugerindo efeito de não identificação, sem proximidade ou contato.

O próximo evento representado no $C B$ com imagem de saliência não humana referese ao grupo atacado com fogo no Guará. Entre os casos que vimos, este é o único que recebeu atenção em mais de uma notícia, propagando-se no tempo. Em termos composicionais, as imagens que acompanharam a maior parte das notícias sobre o caso são bastante similares à fotografia reproduzida na Figura 4, a da árvore. Vejamos um exemplo na Figura 6:

\section{Figura 6 - Fotografia 1/8/2013 com faixa de codificação}

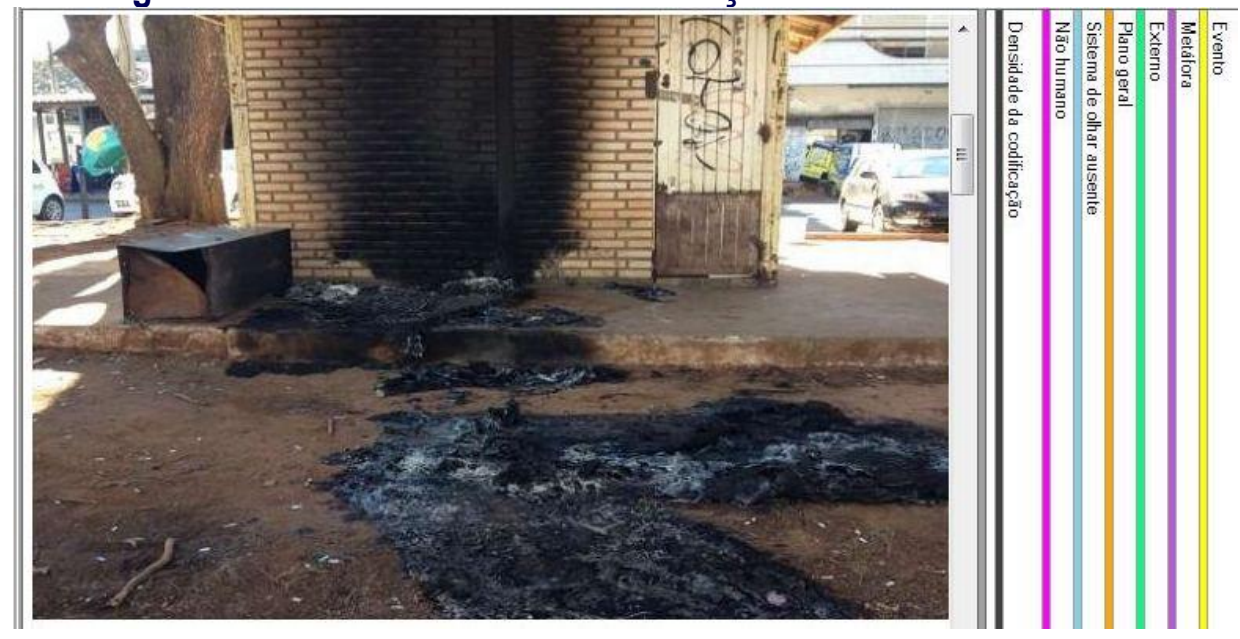

Fonte: Elaboração própria a partir do NVivo 11 Pro e de imagem disponível na Internet ${ }^{6}$

A fotografia compõe a notícia "Homens ateiam fogo em morador de rua; vítima fica com $63 \%$ do corpo queimado". Essa manchete é expandida com "Um grupo de mendigos estava próximo a uma fogueira usada para se esquentar quando suspeitos passaram por eles e atiraram gasolina". A referência ao grupo como "mendigos" é importante aqui, pois sinaliza um modo representacional de avaliação negativa.

6 http://www.correiobraziliense.com.br/app/noticia/cidades/2012/03/10/interna_cidadesdf,292790/doismoradores-de-rua-foram-executados-na-manha-deste-sabado-em-taguatinga.shtml 
Assim como no caso do assassinato de José Edson de Freitas, aqui também o ataque com fogo a um grupo de pessoas em situação de rua é representado por uma imagem do local com as marcas deixadas pelo fogo, em saliência pelo espaço que ocupa na imagem, pela intensidade do foco e da cor preta em contraste com o marrom da terra seca, com zoom e detalhamento da imagem, pelo contraste e pelo enquadramento. Mais uma vez, trata-se de representação subjacente entre evento (ação representada apenas pela meta) e estrutura conceitual simbólica do não corpo metaforicamente representado pela marca do fogo no chão. Esse padrão composicional se repete em outras imagens que viriam a compor notícias sobre o mesmo caso.

$\mathrm{O}$ assassinato $^{7}$ de Edvan Lima foi mencionado no $C B$ em 15 notícias, entre $1^{\circ}$ de agosto e 7 de outubro de 2013. Para outro trabalho, estamos realizando análises detalhadas da cobertura deste caso; por ora apenas dois breves comentários. O primeiro retoma a análise de avaliação na seção anterior: vimos que há poucas avaliações positivas de pessoas em situação de rua no corpus, afeitas a notícias de histórias singulares (outros temas) e a casos de violência; acrescentamos agora que a maior parte das avaliações positivas de pessoas em situação de rua, como pacíficas, trabalhadoras e tranquilas, aparece em notícias sobre o martírio de Edvan Lima. A segunda observação é associada a esta primeira: essas avaliações positivas são articuladas no jornal a vozes de moradores/as locais, e suspeitamos que a mobilização da vizinhança em torno da exigência de justiça para Edvan esteja vinculada à representação mais efetiva desse caso no jornal quando comparada a casos similares.

Poucos dias depois da morte de Edvan Lima, outra pessoa em situação de rua foi atacada com fogo, em 10 de agosto, também no Guará. O homem, identificado como "Paulista", teve $32 \%$ do corpo queimado e sobreviveu ao ataque. A imagem que compõe a única notícia sobre o caso é reproduzida a seguir:

\section{Figura 7 - Fotografia 10/8/2013 com faixa de codificação}

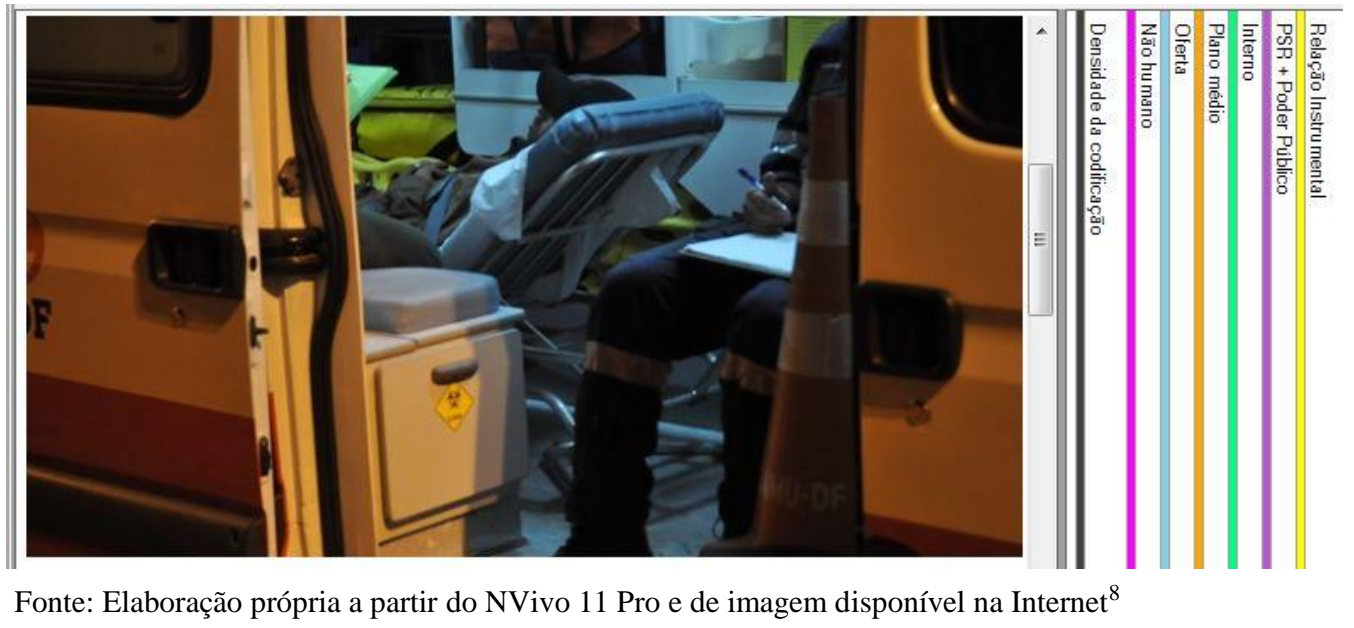

\footnotetext{
7 Na ocasião desta notícia, em $1^{\circ}$ de agosto de 2013, Edvan Lima, de 49 anos, ainda estava vivo, hospitalizado com "aproximadamente $65 \%$ do corpo queimado". Sua morte ocorreu dois dias depois do ataque, mas só viria a ser noticiada no $C B$ em 20 de agosto, quando a polícia prendeu os assassinos. Embora na ocasião do ataque o jornal sugerisse crime entre grupos rivais de pessoas em situação de rua e motivado por briga, depois se descobriu que moradores da cidade do Guará, entre eles a filha de um agente da Polícia Federal, de forma premeditada, haviam atacado o grupo e assassinado Edvan Lima, que dormia na ocasião. 8 http://www.correiobraziliense.com.br/app/noticia/cidades/2013/08/10/interna_cidadesdf,381860/brigamotivou-incendio-a-morador-de-rua-no-guara-ii-diz-testemunha.shtml
}

RESENDE, Viviane de Melo; GOMES, Maria Carmen Aires. Representação da situação de rua no jornalismo eletrônico em textos verbo-visuais - a violência em discurso no Correio Braziliense (2011-2013). Linguagem em (Dis)curso - LemD, Tubarão, SC, v. 18, n. 1, p. 165-191, jan./abr. 2018. 
Diferente das imagens anteriores codificadas com saliência não humana, nesta aparecem duas pessoas, embora uma representada metonimicamente (mão e pernas, mas enfatizando a ação de escrever algo) e outra de costas. A saliência aqui é não humana porque o que recebe intensidade de foco, com maior grau de detalhamento na imagem, não são as pessoas, mas o instrumental do atendimento representado na imagem, que realiza linha de frame: a ambulância. O ângulo horizontal é novamente oblíquo, construindo distanciamento do participante pessoa em situação de rua, que é inclusive retratado de costas.

Em termos da estrutura de representação, codificamos a imagem como de relação instrumental, quando o foco se dá no manuseio de ferramentas. $\mathrm{Na}$ imagem, Paulista é representado recebendo atendimento, o que se realiza não pela presença de alguém que lhe preste cuidados, mas pela maca em que está posicionado, e o agente público também se representa de modo instrumental na ação de preencher dados em uma prancheta. Os corpos representados são de uma pessoa em situação de rua e um representante do poder público, mas eles não se relacionam diretamente na imagem, e não há vetores que estabeleçam conexões entre eles. A imagem configura ação não transacional, pois não há relação entre os participantes humanos ali representados. Observamos um cenário com duas ações acontecendo ao mesmo tempo de maneira encaixada.

No significado interativo, a imagem, diferente das anteriores, é tomada em plano médio, com relativa proximidade com a cena e os participantes representados. Entretanto, no sistema de contato, realiza oferta, já que os participantes representados são oferecidos aos/às observadores/as da imagem como itens de informação, como objetos de contemplação que não voltam olhares para os/as observadores/as.

Temos ainda o último caso: o espancamento de Diego Henrique Vieira Monteiro, de 23 anos, que, ocorrido em 21 de agosto de 2013 em Brazlândia, levou-o à morte:

Figura 8 - Fotografia 21a/8/2013 com faixa de codificação

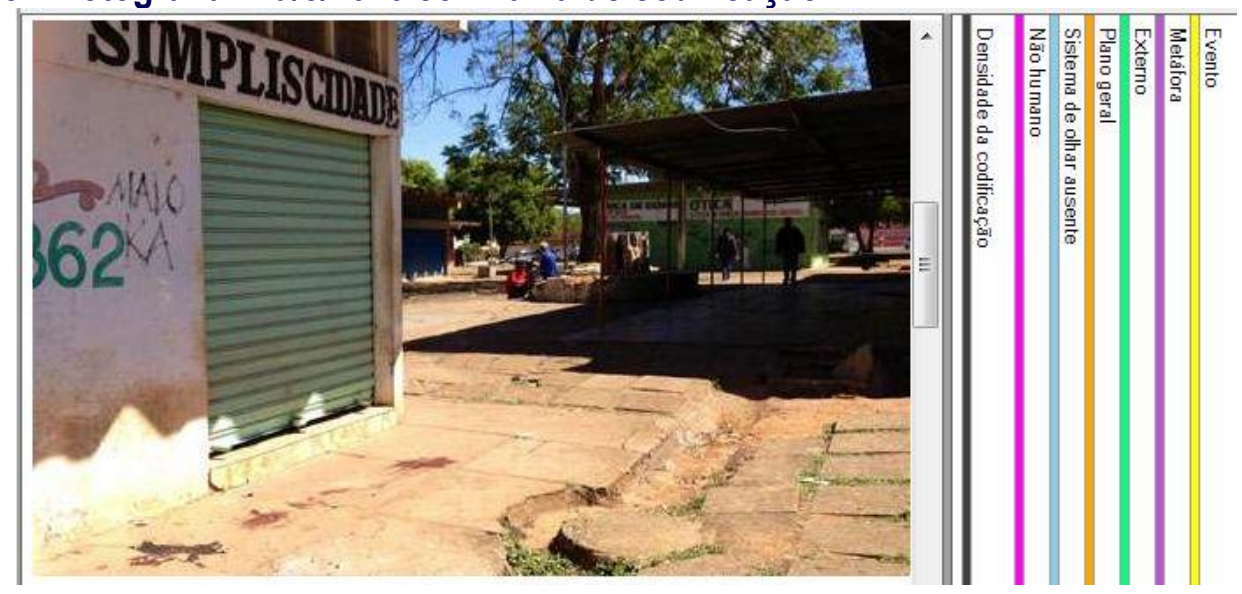

Fonte: Elaboração própria a partir do NVivo 11 Pro e de imagem disponível na Internet ${ }^{9}$

9

http://www.correiobraziliense.com.br/app/noticia/cidades/2013/08/21/interna_cidadesdf,383614/moradorde-rua-morre-apos-ser-espancado-com-pedras-e-barra-de-ferro.shtml 
A imagem compõe a notícia "Morador de rua morre após ser espancado com pedras e barra de ferro". A faixa de codificação à direita da imagem é idêntica à faixa que indica os códigos de análise para a imagem sobre o assassinato de Edvan Lima. Aqui também o corpo é representado conceitualmente por meio de processo simbólico discursivo, mas desta vez pelo rastro de sangue em frente a um estabelecimento comercial, em cenário externo tomado em plano geral, em perspectiva horizontal oblíqua, o que reforça a ideia de rastro do corpo. Codificamos essa imagem, em termos da representação, como de evento, com ação representada apenas pela presença metafórica do corpo de Diego Monteiro, ou seja, pela meta (participante que sofre a ação). Observamos novamente uma construção conceitual ideológica negativa e desimportante subjacente à representação deste não corpo. O crime ocorreu numa praça, mas a imagem sugere uma aproximação da morte de Monteiro com o bar, ao retratar esse evento por meio do ângulo horizontal oblíquo iterando relações causais entre pessoas em situação de rua, álcool e violência, o que potencialmente serviria de justificativa para o assassinato.

Antes de encerrar as análises das imagens que põem em saliência elementos não humanos, precisamos atentar para outra notícia sobre o caso do assassinato de Edvan Lima. A última imagem assim codificada acompanha a notícia "Morador de rua queimado vivo deve ter enterro social", publicada em 2 de setembro de 2013:

Figura 9 - Fotografia 2/9/2013 com faixa de codificação

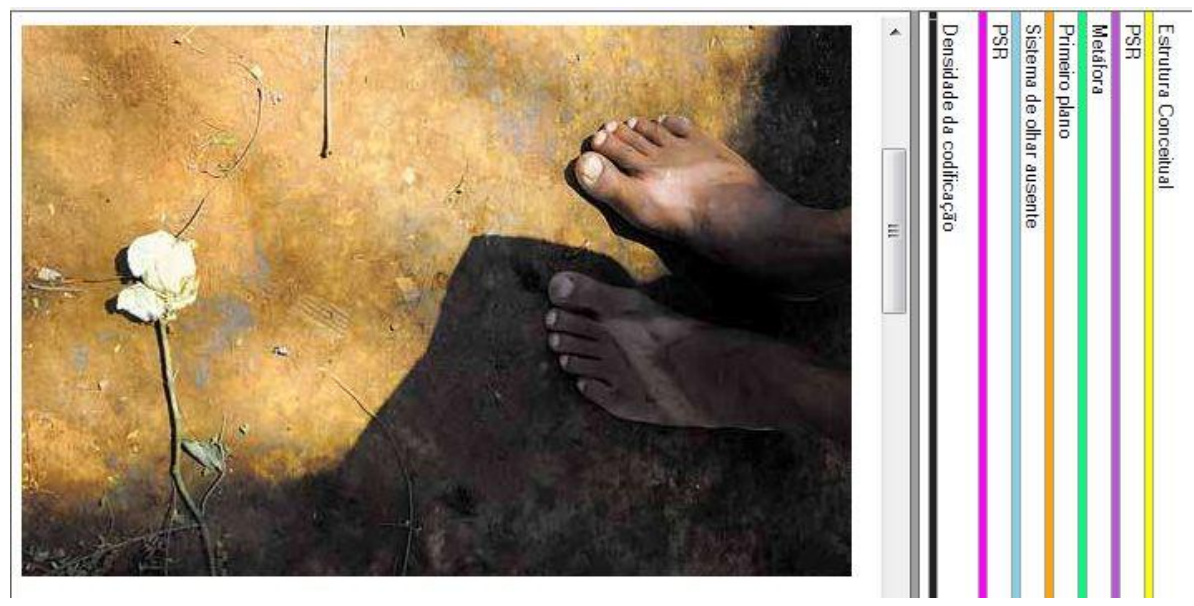

Fonte: Elaboração própria a partir do NVivo 11 Pro e de imagem disponível na Internet ${ }^{10}$

A manchete da notícia é expandida com "O crime ocorreu em $1^{\circ}$ de agosto. Os acusados passaram pelos mendigos, jogaram gasolina e incendiaram as vítimas". Esta imagem tem a seguinte legenda: "Morador de rua, colega de Edvan, na praça onde ocorreu o crime: medo". Embora, pelo contexto, consideremos plausível identificar o corpo representado em primeiro plano à direita da imagem como sendo o de uma pessoa em situação de rua, aqui o que nos parece metafórico é o cenário, que a legenda informa ser a própria praça no Guará onde Edvan Lima foi morto.

10

http://www.correiobraziliense.com.br/app/noticia/cidades/2013/09/02/interna_cidadesdf,385747/moradorde-rua-queimado-vivo-deve-ter-enterro-social.shtml 
Trata-se de uma imagem singular em nosso corpus, absolutamente diferente das demais, com uma composição manipulada para criar um efeito artístico, quase sem diferenciação de cores, em plano muito fechado e uma elevação de ângulo vertical que a afasta da representação imagética própria desse domínio discursivo. Nesse sentido, a imagem, embora naturalística, de representação metonímica, não se adéqua às imagens fotojornalísticas que tratam de violência urbana. A composição, com o pé descalço com marcas de sandália, o solo seco e a flor murcha, não parece saída de um jornal. Diferentemente das outras imagens, há aqui humanização deste sempre-não-corpo, que reforça talvez o sentimento descrito: medo, que implica dessa vez sua humanidade.

Há uma construção representacional conceitual simbólica, tendo a flor branca e murcha como elemento em proeminência por três motivos: a flor encontra-se à esquerda, uma posição privilegiada na imagem pela condução que opera sobre a leitura; a luz está projetada sobre a flor e não sobre o pé descalço; há muito maior contraste entre a flor e o fundo, representado pelo solo, que entre o elemento humano e o solo seco. Essa é uma imagem conceitual: aqui não há ação representada, mas antes a atribuição de características. Entre os participantes representados não há uma relação acional; simplesmente são portadores de atributos que nos remetem a sentidos ligados à pobreza e à aridez.

A seguir, apresentamos o quadro-resumo do mapeamento de categorias do significado interativo, com atenção aos sistemas de contato e de distância.

Tabela 4 - Resumo do mapeamento de categorias para imagens: significado interativo

\begin{tabular}{l|r}
\hline \multicolumn{2}{c}{$\begin{array}{c}\text { IMAGENS - TEXTOS CORREIO BRAZ/LIENSE: VIOLENNCIA } \\
\text { SIGNIFICADO INTERATIVO }\end{array}$} \\
\hline \multicolumn{2}{c}{ Contato } \\
\hline Demanda & 3 \\
Oferta & 6 \\
Sistema de olhar ausente & 10 \\
\hline \multicolumn{2}{c}{ Distância } \\
\hline Plano geral & 11 \\
Plano médio & 3 \\
Primeiro plano & 5 \\
\hline
\end{tabular}

Fonte: Elaboração própria

Consideradas as 19 imagens que compõem os textos cruzando as temáticas situação de rua e violência, as codificações mais recorrentes para o significado interativo são o sistema de olhar ausente, para o sistema de contato, e o plano geral, para o sistema de distância.

Das 10 imagens com sistema de olhar ausente, já vimos cinco (de 6 e de 10 de março de 2012, de $1^{\circ}$ e de 23 de agosto de 2013 e de 6 de setembro de 2013). Outras três compõem imagens do mesmo cenário em que ocorreu o assassinato de Edvan Lima, em produções bastante semelhantes à primeira que vimos sobre o caso, e duas destas reproduzem uma mesma fotografia. Vamos, então, focalizar agora as duas outras imagens que realizam representações com sistema de olhar ausente. 
A Figura 10, a seguir, compõe a notícia "Morador de rua é encontrado morto com sinais de envenenamento no Plano", publicada em 30 de agosto de 2012, que narra o assassinato do jovem de 25 anos apresentado no texto simplesmente como "Alex". Ele "foi encontrado morto" no Setor Comercial Sul, no centro de Brasília. Outras duas pessoas, referidas na notícia como "mendigos", também foram envenenadas, e embora tenham sido socorridas e levadas ao hospital, também morreram, dias depois.

Figura 10 - Fotografia 30/8/2012 com faixa de codificação

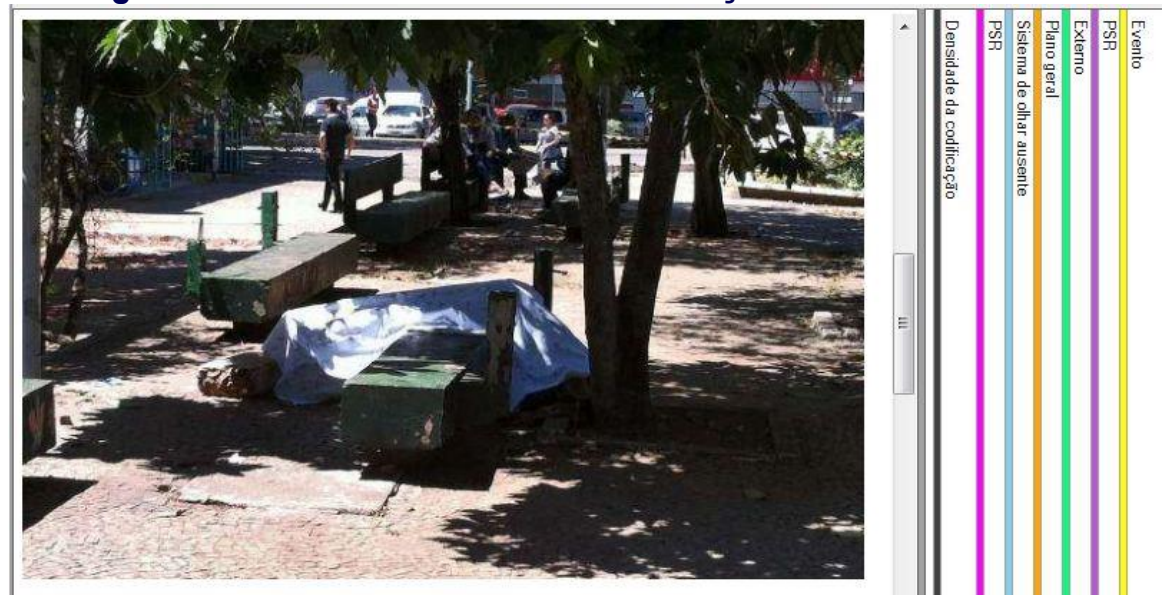

Fonte: Elaboração própria a partir do NVivo 11 Pro e de imagem disponível na Internet ${ }^{11}$

A fotografia tomada em plano geral inclui circunstâncias locativas em cenário externo, que tem em saliência um corpo morto coberto com um lençol. Há pessoas no plano de fundo do cenário, mas o sistema de olhar está ausente, não havendo nenhuma possibilidade de contato entre os participantes representados e o/a observador da imagem. Em termos representacionais, temos mais uma estrutura de evento em que se mostra apenas o alvo da ação violenta representada, em situação de encaixe com estrutura conceitual simbólica. Estrutura representacional semelhante apresenta-se na Figura 11 a seguir, embora com distinta saliência:

A imagem compõe a notícia "Morador de rua leva dois tiros e morre na região do Pombal, em Planaltina". Na faixa de codificação, vemos a descrição da imagem nas categorias mapeadas nos dados: em termos representacionais, a imagem realiza estrutura similar à anterior, com subjacência entre representação de evento e estrutura conceitual simbólica, mas com saliência da força de segurança pública, pelo espaço que a viatura ocupa, pela intensidade do foco sobre ela, pela perspectiva no primeiro plano, por seu contraste com o cenário no plano de fundo, onde se vê o corpo da pessoa assassinada, coberto e enquadrado por cones que também remetem às forças da ordem pública. Embora haja um policial dentro da viatura, o sistema de contato aqui também está ausente, pelo efeito de sombra projetado sobre o rosto do policial.

11

http://www.correiobraziliense.com.br/app/noticia/cidades/2012/08/30/interna_cidadesdf,319927/moradorde-rua-e-encontrado-morto-com-sinais-de-envenenamento-no-plano.shtml 
Figura 11 - Fotografia 2/12/2012 com faixa de codificação

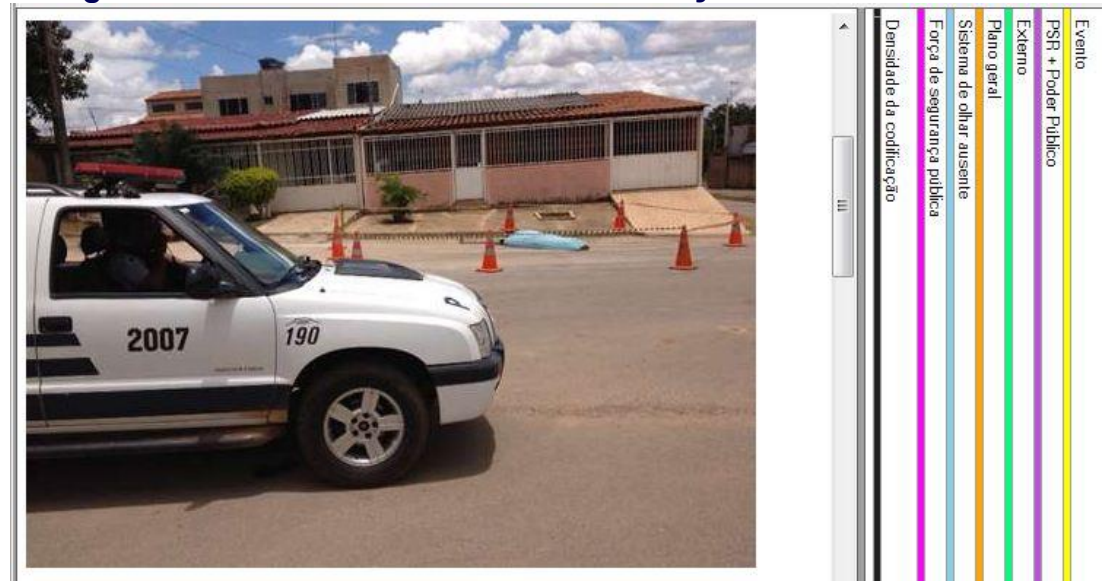

Fonte: Elaboração própria a partir do NVivo 11 Pro e de imagem disponível na Internet ${ }^{12}$

Nosso mapeamento também apontou predominância de imagens em plano geral: 11 das 19 imagens de nosso corpus têm plano aberto, incluindo cenários e características circunstanciais locativas. Das 11 imagens em plano geral já vimos nove; vejamos, então, as duas que nos faltam:

Figura 12 - Fotografia 5/7/2012 com faixa de codificação

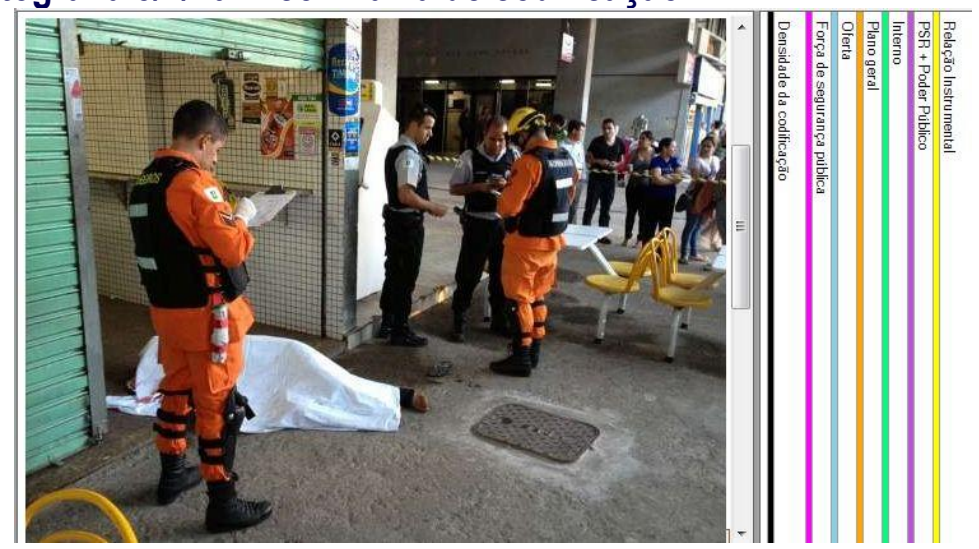

Fonte: Elaboração própria a partir do NVivo 11 Pro e de imagem disponível na Internet ${ }^{13}$

A fotografia compõe a notícia "Morador de rua morre esfaqueado na Quadra 6 do Setor Comercial Sul", publicada em 5 de julho de 2012. Em plano aberto, com ângulo horizontal oblíquo, a imagem inclui detalhes do cenário, e a linha de frame formada pela faixa policial posta ao fundo separa a zona focal, onde estão os representantes da ordem pública que agem na narrativa instrumental e o corpo coberto por lençol, e a zona de

12

http://www.correiobraziliense.com.br/app/noticia/cidades/2012/12/02/interna_cidadesdf,336934/moradorde-rua-leva-dois-tiros-e-morre-na-regiao-do-pombal-em-planaltina.shtml 13

http://www.correiobraziliense.com.br/app/noticia/cidades/2012/07/05/interna_cidadesdf,310801/moradorde-rua-morre-esfaqueado-na-quadra-6-do-setor-comercial-sul.shtml 
fundo, onde estão outras pessoas. O homem morto não é identificado, pois tanto ele quanto o suspeito do crime, segundo a voz policial referida na matéria, não portariam documentos de identidade. O elemento em saliência é a força da ordem pública, tanto pela posição que ocupa na imagem quanto pelo contraste de cores. A imagem projeta-se como oferta: não há olhar direto entre participantes representados e observador/a da imagem. Os participantes representando a ordem pública estão fotografados de costas ou de perfil para o/a leitor/a, oferecendo uma imagem sugestiva de sua ação em prol da segurança pública.

A última imagem de plano geral que nos falta analisar foi publicada na notícia "Flanelinha é suspeito de matar desabrigado a facadas no Parque da Cidade", de 12 de março de 2013:

\section{Figura 13 - Fotografia 12/3/2013 com faixa de codificação}

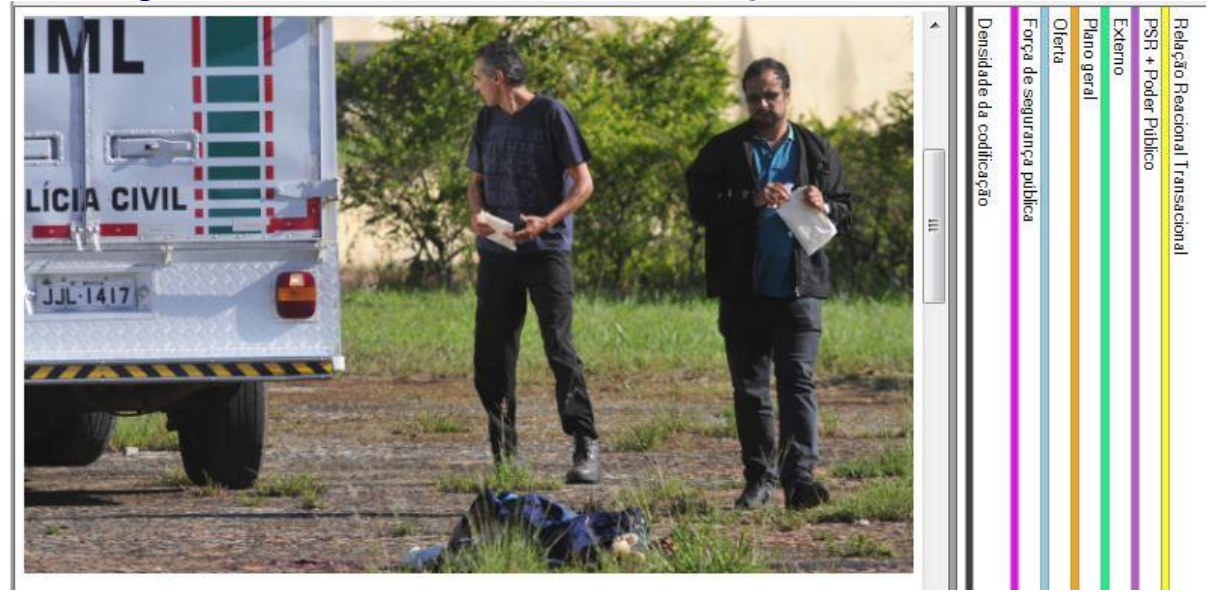

Fonte: Elaboração própria a partir do NVivo 11 Pro e de imagem disponível na Internet ${ }^{14}$

Nesse caso, temos outro tipo de estrutura de representação, que codificamos como uma relação reacional transacional. Segundo Kress e van Leeuwen (1996, p. 84), "[q]uando o vetor é formado por uma linha dos olhos, pela direção do relance de um ou mais dos participantes representados, o processo é reacional". Na imagem, os policiais são reagentes, pois observam e reagem, um ao corpo da pessoa em situação de rua, junto ao chão; o outro olhando em direção à viatura. $\mathrm{O}$ plano aberto permite vislumbrar o cenário, que é dominado pela viatura policial alinhada aos policiais, uma extensão da ordem e da segurança. A saliência é evidente neste caso - a força de segurança pública representada tanto pela viatura como pelas duas figuras humanas de pé. O corpo no chão, entretanto, é bastante obscurecido, tanto por sua posição muito baixa quanto pela vegetação que o cobre parcialmente. Ao contrário dos corpos mortos nas imagens antecedentes, que aparecem destacados sob lençóis claros, este está quase camuflado pelo mato. Como os policiais não realizam vetor de olhar com o/a observador/a, esta é também uma imagem de oferta, em que se oferece antes a ideia de proteção, de ordem e de segurança do que a do corpo da vítima.

14

http://www.correiobraziliense.com.br/app/noticia/cidades/2013/03/12/interna_cidadesdf,354196/flanelinh a-e-suspeito-de-matar-desabrigado-a-facadas-no-parque-da-cidade.shtml 
Por fim, vejamos ainda o que a Tabela 5, que resume a codificação para o significado representacional, nos aponta como recorrências: Tabela 5 - Resumo do mapeamento de categorias para imagens: significado
representacional

\begin{tabular}{|c|c|}
\hline \multicolumn{2}{|c|}{$\begin{array}{l}\text { IMAGENS - TEXTOS CORREIO BRAZ/LIENSE: VIOLÊNCIA } \\
\text { SIGNIFICADOS REPRESENTACIONAIS }\end{array}$} \\
\hline \multicolumn{2}{|c|}{ Cenário } \\
\hline Externo & 15 \\
\hline Interno & 5 \\
\hline Metáfora & 1 \\
\hline \multicolumn{2}{|l|}{ Corpo representado } \\
\hline Agressores de pessoas em situação de rua & 2 \\
\hline Coletivo & 1 \\
\hline Metáfora & 6 \\
\hline Polícia & 1 \\
\hline Pessoa em situação de rua & 5 \\
\hline Pessoa em situação de rua + Poder público & 4 \\
\hline \multicolumn{2}{|c|}{ Tipos de estruturas de representação } \\
\hline Conceitual & 4 \\
\hline Narrativa Transacional & 1 \\
\hline Narrativa Não Transacional & 1 \\
\hline Narrativa Eventual (inclui metáfora) & 9 \\
\hline Narrativa Instrumental & 2 \\
\hline Narrativa Reacional Transacional & 1 \\
\hline Narrativa Reacional Não Transacional & 1 \\
\hline
\end{tabular}

Fonte: Elaboração própria

A Tabela 5 mostra o mapeamento de categorias de representação nas 19 imagens do corpus do $C B$ cruzando situação de rua e violência. Das 15 imagens codificadas em cenário externo, já vimos quase todas, faltando apenas uma. As seis imagens em que o corpo representado foi codificado como corpo-metáfora já foram analisadas, assim como as nove imagens que receberam codificação em tipos de estrutura de representação de evento com processos conceituais simbólicos subjacentes. Assim, neste olhar dirigido pelas recorrências representacionais na codificação do corpus, só nos falta uma imagem para cumprir a tarefa (ver figura 14, na página seguinte):

A imagem é incluída em nossa análise de recorrências por ser a única codificada em cenário externo - codificação de 15 das 19 imagens - que ainda não havia sido apresentada. $\mathrm{O}$ elemento em saliência nessa imagem é claramente a força de ordem pública: a viatura policial aparece ocupando a maior parte da fotografia, em ângulo horizontal oblíquo que favorece o foco na palavra escrita no carro em letras garrafais: "criminalística". Além disso, há outro veículo policial, um carro menor ao fundo, e todas as figuras humanas na imagem remetem às corporações policiais e interagem entre si.

A imagem realiza estrutura representacional narrativa transacional, pelo vetor que se forma entre os dois policiais à esquerda da imagem, mas a narrativa que se projeta entre os dois policiais mais à direita poderia ser classificada como relação reacional transacional, em que o policial mais ao fundo reage com o olhar ao outro que se aproxima. A imagem é fechada no escopo policial: todos os participantes representados são assim identificados, sua ação é circunscrita a eles mesmos e a imagem é dominada pela viatura, sobre a qual recai toda atenção, por aspectos como tamanho das letras, intensidade do foco, detalhes da imagem, contraste, tonalidades, brilho, perspectiva e posicionamento. 
Figura 14 - Fotografia 28/9/2012 com faixa de codificação

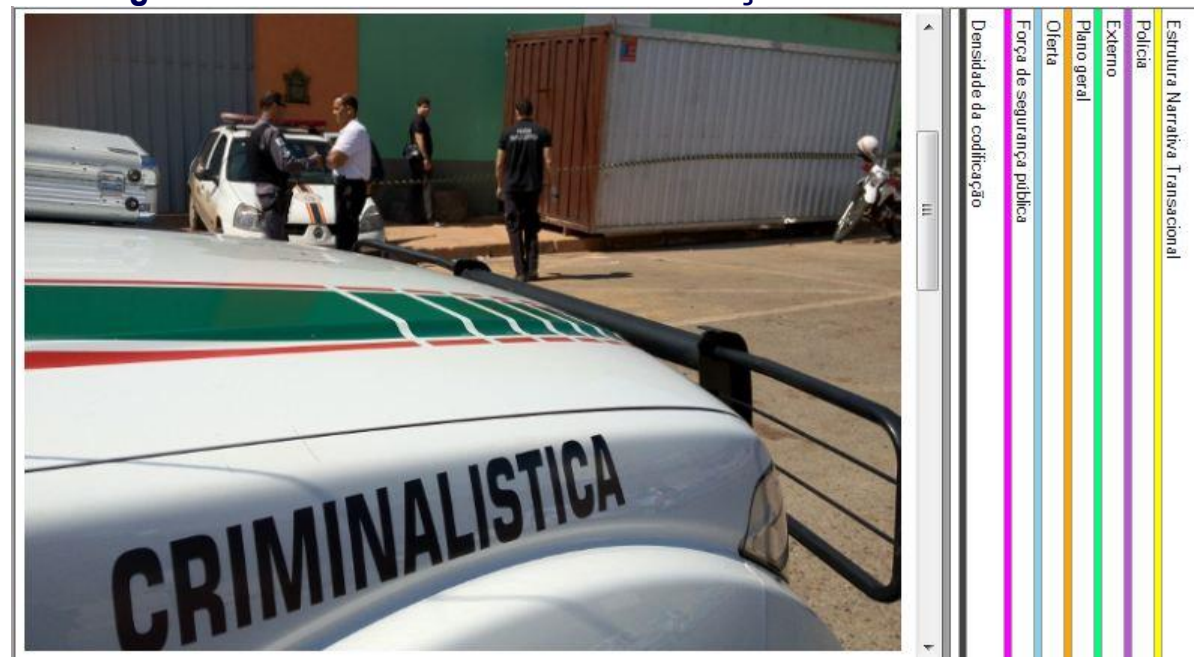

Fonte: Elaboração própria a partir do NVivo 11 Pro e de imagem disponível na Internet ${ }^{15}$

Embora a notícia "Moradora de rua é encontrada morta atrás de supermercado em Taguatinga", de 28 de setembro de 2012, seja sobre o assassinato de uma jovem em situação de rua, que teria sido, segundo a voz policial articulada na matéria, "estuprada e asfixiada", a imagem se limita a mostrar a ação policial se desenrolando nos fundos do supermercado, cenário da morte dessa mulher sem nome, identificada apenas como "uma moradora de rua".

\section{CONSIDERAÇÕES FINAIS}

Neste artigo, foram considerados 166 textos, com ênfase em 95 que tematizam violência e em 19 destes que incluem fotografias em sua composição. A análise panorâmica do material verbal pautou-se pelas categorias de intertextualidade e avaliação, e a análise das imagens considerou saliência, contato, distância, estrutura de representação, cenário e corpo representado.

O mapeamento aponta a violência como o tema mais carregado de diferentes vozes, e as principais avaliações sobre pessoas em situação de rua orbitam discursos de incômodo e risco, fato paradoxal em relação à predominância de casos em que pessoas em situação de rua são vítimas de violência (RESENDE, 2016; RESENDE, RAMALHO, 2017). Os modos mais recorrentes de referência a pessoas em situação de rua são 'morador de rua' (em 58 referências), 'vítima' (em 24 referências) e 'mendigo' (em 21 referências).

Se retomarmos esses três modos de referência no corpus total do $C B$, encontramos outras 36 referências como 'morador de rua', mas apenas mais uma como 'mendigo'. Assim, a utilização desse item lexical de teor pejorativo é bastante restrito aos casos em que pessoas em situação de rua são assassinadas. Isso pode tender a funcionar como uma

http://www.correiobraziliense.com.br/app/noticia/cidades/2013/03/12/interna_cidadesdf,354196/flanelinh a-e-suspeito-de-matar-desabrigado-a-facadas-no-parque-da-cidade.shtml 
espécie de justificativa, operando uma mitigação da violência - do mesmo modo como ocorreu no caso do assassinato do pataxó Galdino. Os padrões de colocação de fogo (atear fogo), de queimado (corpo queimado, morador de rua queimado) e de incendiar (incendiar morador de rua) também indicam naturalização (sobre isso, ver também RESENDE; RAMALHO, 2017).

Nas imagens, são recorrentes: saliência de elementos não humanos, em estruturas representacionais que tendem ao eventual com representação metafórica do alvo da violência, com subjacência de processo conceitual simbólico; conceituação da ordem policial de maneira classificatória, em que viaturas, policiais, faixas de segurança e cones se relacionam de maneira taxonômica, subordinando-se ao conceito de segurança pública; tomada em plano geral de cenário externo com detalhamento e teor circunstancial, produzindo cenários marcantes de violência; realização de imagens de oferta, com efeito potencial de distanciamento em relação à situação representada, especialmente quando em composição com ângulo horizontal oblíquo.

As análises sugerem naturalização da violência contra a população em situação de rua, num efeito retórico de distanciamento, que não provoca empatia entre quem lê o jornal e as pessoas vítimas da violência representada. Essa violência, ainda que bárbara e dirigida a pessoas com pouca chance de defesa, é normalizada. Retomando a epígrafe com que iniciamos este texto, não podemos desvincular a violência privada da violência institucionalizada: cada martírio descrito no corpus que tomamos para esta investigação tem seus autores individuais, mas não se descola da rotineira violência institucional. Referimo-nos à violência simbólica da representação, mas também à violência da violação de direitos. São pessoas que sofrem a carência, vítimas preferenciais da violência institucional da polícia, da justiça e da sociedade de modo mais amplo. Sua representação pejorativa sugere a mais completa falta de solidariedade, essa desidentificação que nos permite viver tranquilamente nossas vidas, nos ocupando de nossos corpos mercantilizados, enquanto outras pessoas padecem e outros corpos são deixados para morrer.

\section{AGRADECIMENTOS}

Agradecemos ao CNPq o reconhecimento, na forma da bolsa de pesquisa concedida pelo projeto de investigação "Representação midiática da violação de direitos e da violência contra pessoas em situação de rua no jornalismo on-line" (CNPq 304075/20140). À Ingrid Ramalho agradecemos por haver coletado e organizado dados do portal do Correio Braziliense; à Mariana Moura, por igual trabalho no portal de O Globo; à Lygia Vaz, pelo empenho com os dados intermináveis da Folha de S. Paulo; à Dara Abreu e à Daniele Mendonça, por darem continuidade ao extenso trabalho com a Folha de S. Paulo, e a esta última também por nos enriquecer com seus conhecimentos de jornalismo; à colega Carolina Araújo, por seu apoio com o NVivo, e por estar presente nas sempre necessárias orientações que lhe demandamos, sendo ativa colaboradora do Laboratório de Estudos Críticos do Discurso (LabEC/UnB) e do Núcleo de Estudos de Linguagem e Sociedade (NELiS/UnB); ao Programa de Pós-Graduação em Estudos Linguísticos da UFMG, pela oportunidade da parceria no pós-doutorado, em que os dados de imagens do Correio Braziliense e de O Globo foram analisados. 
BIASI-RODRIGUES, B; NOBRE, K.C. Sobre a função das representações conceituais simbólicas na gramática do design visual: encaixamento ou subjacência. Linguagem em (Dis)curso, v. 10, n. 1, p. 91109, 2010

BOLÍVAR, A. A change in focus: from texts in contexts to people in events. Journal of Multicultural Discourses, v. 5, n. 3, p. 213-226, 2010.

DAVIS, A. Feminismo negro e a luta mundial por equidade. Conferência proferida no Festival Latinidades. Brasília: Museu da República, 24 jul. 2014.

FAIRCLOUGH, N. Analysing discourse: textual analysis for social research. London: Routledge, 2003.

Critical discourse analysis: the critical study of language. 2ed. New York: Longman, 2010.

FANON, F. Pele negra máscaras brancas. Salvador: UFBA, 2015.

FOUCAULT, M. What is Enlightenment? In: P. Rabinow (Org.). The Foucault Reader. New York: Pantheon Books, 1984. p. 32-50.

KRESS, G.; VAN LEEUWEN, T. Reading images: the grammar of visual design. London; New York: Routledge, 1996.

LE BRETON, D. O paradigma da corporeidade na contemporaneidade. Conferência proferida na Universidade de Brasília, Instituto de Ciências Sociais, 10 mar. 2017.

PARDO ABRIL, N. G. Programa Diálogos, entrevista à UnBTV. Brasília, novembro de 2016. Disponível em: <https://www.youtube.com/watch?v=U11np5KY260>. Acesso em: 6 mar. 2018.

PARDO, M. L. Latin-American discourse studies: state of the art and new perspectives. Journal of Multicultural Discourses, v. 5, n. 3, p. 183-192, 2010.

RESENDE, V. Representação de pessoas em situação de rua no jornalismo on-line: quais são as vozes convocadas para falar sobre a situação de rua? Revista de Estudos da Linguagem, v. 26, n. 3, p. 955-988, 2016.

Reflexões teóricas e epistemológicas quase excessivas de uma analista obstinada. In: RESENDE, V.; REGIS, J. (Org.). Outras perspectivas em análise de discurso crítica. Campinas: Pontes, 2017. p. 1152.

Representação discursiva de pessoas em situação de rua no Caderno Brasília: naturalização e expurgo do outro. Linguagem em (Dis)curso, n. 12, n. 2, p. 439-465, 2012.

A violação de direitos da população em situação de rua e a violência simbólica: representação discursiva no jornalismo on-line. Revista Latinoamericana de Estudios del Discurso, v. 15, p. 71-92, 2015a.

Violência simbólica: representação discursiva da extrema pobreza no Brasil - relações entre situação de rua e vizinhança. Discurso \& Sociedad, v. 9, p. 106-128, 2015 b.

RESENDE, V. M.; RAMALHO, I. S. Representação midiática da violação de direitos e da violência contra pessoas em situação de rua no Correio Web. Calidoscópio, v. 15, n. 3, p. 529-541, 2017.

RESENDE, V. M.; RAMALHO, V. Inequality and representation: critical discourse analysis of news coverage about homelessness. In: PASCALE, C. M. (Org.). Social inequality \& the politics of representation: a global landscape. Washington: Sage, 2013. p. 21-34.

RESENDE, V. M.; SANTOS, A. A. A representação de pessoas em situação de rua quando vítimas de chacina: uma análise discursiva crítica. Revista Latinoamericana de Estudios del Discurso, n. 12, p. 81102, 2012.

RESENDE, V. M; SILVA, R. B. Análise de discurso crítica e comunicação: quem é Rafael Braga Vieira em $O$ Globo.com? In: MAGALHÃES, L. (Org.). Análise de Discurso Crítica e Comunicação: percursos teórico e pragmático de discurso, mídia e política. Teresina: UFPI, 2017.

SEARA, I. R. Palestra na mesa redonda "Discurso e exclusão em contextos midiáticos”, IV Simpósio Internacional de Análise de Discurso, setembro de 2016, não publicada em anais. Belo Horizonte: UFMG, 2016.

TIBURI, M. Judith Butler: feminismo como provocação. Revista Cult. Ano 16, n. 185, p. 23, 2013. VAN LEEUWEN, T. A representação dos actores sociais. In: PEDRO, E. R. (Org.). Análise crítica do discurso: uma perspectiva sociopolítica e funcional. Lisboa: Caminho, 1997. 
Introducing Social Semiotics. London; New York: Routledge, 2005.

Discourse and practices. Oxford: Oxford University Press, 2008.

VIEIRA, V. C.; RESENDE, V. M. Análise de discurso (para a) crítica: o texto como material de pesquisa. 2 ed. Campinas: Pontes, 2016.

Recebido em: 17/06/17. Aprovado em: 25/02/18.

Title: Representation of homelessness in electronic journalism in verb-visual texts - violence in discourse in the Correio Braziliense newspapers (2011-2013)

Authors: Viviane de Melo Resende; Maria Carmen Aires Gomes

Abstract: This paper discusses part of a research project aiming to investigate texts about homelessness published between 2011 and 2013 in the newspapers Correio Braziliense, $\mathrm{O}$ Globo and Folha de S. Paulo. In this paper, we analyze only the 95 texts published in Correio Braziliense crossing the themes homelessness and violence, and the 19 images that compose these texts. To organize data, we have used software for qualitative analysis, and textual analyses were driven by critical discourse analysis and the grammar of visual design. Taken together, the results suggest the naturalization of violence against the homeless population, in a rhetorical effect of distancing, which does not provoke empathy between those who read the newspaper and the victims of the represented violence.

Keywords: Critical discourse analysis. Homelessness. Violence. Cyber journalism.

Título: Representación de la situación de calle en el periodismo eletrónico en textos verbovisuales - la violencia en discurso en el Correio Braziliense (2011-2013)

Autoras: Viviane de Melo Resende; Maria Carmen Aires Gomes

Resumen: Este artículos es un recorte de proyecto de investigación en que se han investigado los textos publicados entre 2011 y 2013 en los periódicos web Correio Braziliense, O Globo $y$ Folha de S. Paulo sobre populación en situación de calle. En este recorte se analizan sólo los 95 textos publicados en el Correio Braziliense, cruzando las temáticas de situación de calle y violencia y las 19 imágenes que componen los textos. El análisis presentado é favorecido por el uso de software para análisis cualitativo, y tiene por base teóricometodológico el análisis del discurso crítico y la gramática del diseño visual. Adoptados juntos, los resultados del análisis sugieren naturalización de la violencia contra la populación en situación de calle, en un efecto retórico de alejamiento, que no provoca empatía entre quienes lee el periódico y las personas víctimas de la violencia representada.

Palabras-clave: Análisis de discurso crítica. Situación de calle. Violencia. Periodismo Web.

Este texto está licenciado com uma Licença Creative Commons Atribuição 4.0 Internacional.

RESENDE, Viviane de Melo; GOMES, Maria Carmen Aires. Representação da situação de rua no jornalismo eletrônico em textos verbo-visuais - a violência em discurso no Correio Braziliense (2011-2013). Linguagem em (Dis)curso - LemD, Tubarão, SC, v. 18, n. 1, p. 165-191, jan./abr. 2018. 